\title{
Dietary supplementation of tilapia juveniles reared in bft (bioflocs) tanks with dl-methionine
}

\section{Suplementação da dieta de juvenis de tilápia criados em tanques bft (bioflocos) com dl-metionina}

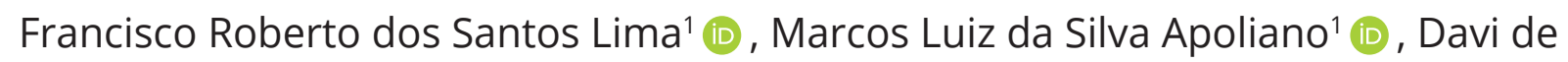
Holanda Cavalcante1 (iD , Marcelo Vinícius Carmo Sá1* (iD)

${ }^{1}$ Universidade Federal do Ceará, CE, Brazil

${ }^{*}$ Correspondent - marcelo.sa@ufc.br

Received

June 12, 2020

Accepted

December 21, 2020.

Published

May 11, 2021.

www.revistas.ufg.br/vet visit the website to get the how to cite in the article page.

\begin{abstract}
The present study aimed at determining the effects of dietary DL-methionine supplementation on the water quality, bioflocs composition and Nile tilapia juvenile's (initial body weight $=2.76 \pm 0.06 \mathrm{~g}$ ) growth performance in BFT rearing tanks (18 fish/100-L tank). Fish were or not subjected to artificial feed restriction. The experimental treatments consisted of two control groups: 1 - no feed restriction, no methionine supplementation; 2 - feed restriction at $25 \%$, no methionine supplementation. There were also four treated groups: 1 - feed restriction at $25 \%$, dietary DL-methionine supplementation at $0.5 \%$; 2 - feed restriction at 25\%, dietary DL-methionine supplementation at $1.0 \% ; 3$ - feed restriction at $25 \%$, dietary DL-methionine supplementation at $2.0 \% ; 4$ - feed restriction at $25 \%$, DL-methionine supplementation of molasses at 1.0. Supplementation of the commercial diet with DL-methionine has not affected either the water quality of the BFT Nile tilapia rearing tanks or the proximate composition of the bioflocs. After 8 weeks, weight gain of fish reared in tanks with feed restriction and dietary DL-methionine supplementation at $1 \%$ or $2 \%$ has not differed $(P>0.05)$ from the tanks without feed restriction. In conclusion, it is possible to restrict the daily feed allowances of Nile tilapia juveniles reared in BFT tanks at 25\%, with no growth performance impairment, if a minimal dietary DL-methionine supplementation of $1.0 \%$ is given.
\end{abstract}

Keywords: Bioflocs. Amino acid. Aquaculture. Water quality.

\begin{abstract}
Resumo
O presente estudo teve por objetivo determinar os efeitos da suplementação da ração balanceada de juvenis de tilápia do Nilo (peso médio inicial $=2,76 \pm 0,06 \mathrm{~g}$ ), submetidos à restrição na oferta de alimento artificial em tanques BFT de cultivo (18 juvenis/tanque 100 L), com DL-metionina, sobre a qualidade da água, composição dos bioflocos e desempenho zootécnico. Os tratamentos experimentais foram constituídos por dois grupos controle: 1 - sem restrição alimentar, sem suplementação com metionina; 2 - com restrição alimentar de $25 \%$, sem suplementação com metionina. Os quatro
\end{abstract}


tratamentos experimentais foram os seguintes: 1 - restrição alimentar de $25 \%$, suplementação da ração com 0,5\% de DL-metionina misturada à ração; 2 - restrição alimentar de $25 \%$, suplementação da ração com $1,0 \%$ de DL-metionina misturada à ração; 3 - restrição alimentar de $25 \%$, suplementação da ração com $2,0 \%$ de DL-metionina misturada à ração; 4 - restrição alimentar de $25 \%$, suplementação do melaço em $1,0 \%$ de DL-metionina. A suplementação da ração balanceada com DL-metionina não afetou a qualidade da água de cultivo de juvenis de tilápia do Nilo, em tanques BFT, nem a composição centesimal do bioflocos. Após 8 semanas, o ganho em peso corporal dos peixes mantidos nos tanques com restrição alimentar e suplementação da ração com $1 \%$ ou $2 \%$ de DL-metionina não diferiu $(P>0,05)$ do observado nos tanques sem restrição alimentar. Concluiu-se que é possível restringir as taxas de arraçoamento de juvenis de tilápia do Nilo, mantidos em tanques BFT de cultivo, em $25 \%$, sem prejuízo zootécnico, desde que se faça a suplementação da dieta com, pelo menos, $1 \%$ de DL-metionina.

Palavras-chave: Bioflocos. Aminoácido. Aquicultura. Qualidade de água.

\section{Introduction}

Bioflocs are aggregates made up of different microorganisms, animal feces and other organic particles. In addition to improving water quality, bioflocs also serve as a food source for some species of fish and shrimp, such as Nile tilapia, Oreochromis niloticus, and marine shrimp, Litopenaeus vannamei(1,2). The biofloc technology (BFT) applied to aquaculture aims to control water quality by favoring the development of heterotrophic and nitrifying bacteria capable of removing ammonia and nitrite in tanks with minimal or zero-water exchange ${ }^{(1,3,4)}$. The BFT technology is applied to superintensive closed aquaculture systems, being advantageous both economically and epidemiologically. Bioflocs may have a probiotic role, acting to prevent the development of pathogenic bacteria and improve the activity of digestive enzymes in fish and shrimp ${ }^{(4,5)}$.

Ingestion of bioflocs can partially meet the nutritional requirements of fish and shrimp and reduce commercial feed costs ${ }^{(6)}$. In studies carried out with tilapia and $L$. vannamei, bioflocs allowed a decrease in dietary protein without growth performance impairment $t^{(1,7,8,9)}$. Therefore, the amino acids, fatty acids, vitamins, and minerals of bioflocs might reduce the need of nutritionally complete diets ${ }^{(10)}$.

However, the bioflocs value as a food source for farmed fish and shrimp is unpredictable because there is great variability in its chemical composition. The source of organic carbon used to adjust the $\mathrm{C}$ : $\mathrm{N}$ ratio of water and the water quality are some factors that affect the bioflocs proximate composition ${ }^{(2,11)}$. While Ballester et al. ${ }^{(12)}$ observed circa of $30 \%$ and $5 \%$ proteins and lipids, respectively, in the bioflocs biomass, Durigon et al. ${ }^{(13)}$ reported only $17 \%$ and $1 \%$, respectively, in tilapia tanks. 
Although bioflocs might be an important source of essential amino acids, some studies have shown they are generally deficient in methionine to meet tilapia and L. vannamei's requirements ${ }^{(11,14,15,16)}$. The development of a feeding strategy to correct the bioflocs' methionine deficiency would be of importance for economic sustainability of the activity. The present study aimed at determining the effects of the supplementation of a commercial feed with DL-methionine on water quality, composition of bioflocs and Nile tilapia growth performance, in BFT tanks under feed restriction.

\section{Material and methods}

Nile tilapia (Oreochromis niloticus) juveniles were obtained from a regional producer (Itaitinga, Ceará), transported to the laboratory facilities, and transferred to an acclimation tank. The study was carried out in the lab indoor culture system, which consists of 30 circular polyethylene 100-L tanks. Each tank was initially supplied with $70 \mathrm{~L}$ freshwater and $30 \mathrm{~L}$ bioflocs-rich water obtained from one 1000-L outdoor tank. The bioflocs tank had 30 juveniles of Nile tilapia with an average weight of $31.6 \pm 3.4$ g. Fish were fed with a commercial powdered diet for omnivorous tropical fish (40\% crude protein), four times daily, at $8,11,14$ and $17 \mathrm{~h}$, at a rate of $7.5 \%$. The bioflocs were harvested after 21 days. The adjustment of the water C: $\mathrm{N}$ ratio to 15: 1 was performed by applying dry molasses to water, following the recommendations of Avnimelech(17).

Tanks were mechanically aerated with a radial compressor (air blower) with a nominal power of $2.5 \mathrm{hp}$. Tanks were continuously aerated throughout the study. Each tank was provided with an air adjuster and a microporous hose ( $25 \mathrm{~cm}$ long; $2.5 \mathrm{~cm}$ in diameter), linearly arranged at the tank center for air dispersion in water. There was no water exchange over the entire experiment, only the replacement to maintain the initial water level.

At the beginning of the study, each rearing tank was stored with 18 juveniles of Nile tilapia with a body weight of $2.76 \pm 0.06$ at $49.6 \pm 1.0 \mathrm{~g}$ fish per tank of $100 \mathrm{~L}\left(\approx 500 \mathrm{~g}\right.$ fish $\left.\mathrm{m}^{-3}\right)$. The completely randomized design consisted of two control groups and four experimental groups with five replications each (30 tanks in total). Fish in the positive control were fed regularly, completely following the feeding rates of the laboratory $(\approx 8 \%$ biomass day $^{-1}$ ). Besides, the commercial diet had no supplementation with DL-methionine $99 \%$ (MetAMINO ${ }^{\circledR}$, Evonik Animal Nutrition Ltda). Fish in the negative control group received only $75 \%$ dietary allowance of the positive group and no methionine supplementation. Fish in three experimental groups received $75 \%$ daily dietary allowance ${ }^{(18)}$, but their commercial diet was supplemented with increasing levels of DL-methionine $(0.5 ; 1.0$ and 2.0\%). The DL-methionine was blended to the amounts of artificial diet offered in each tank as follows: the designed amounts of DL-methionine $(0.5 \% ; 1.0 \% 2.0 \%)$ were manually mixed with the artificial diet with the aid of a glass rod; the daily amounts of diet supplemented with DL-methionine were weighed and stored in plastic bags until use. In one of the experimental groups, fish received $75 \%$ artificial diet, but the $1.0 \%$ DL-methionine was supplemented to the dry molasses instead of the diet.

Fish were fed for eight weeks, four times a day at 8,11,14 and 17h, with commercial 
powdered diet for omnivorous fish (Aquamix PL-0, Integral Mix, Fortaleza, Ceará). After weighing fish fortnightly, the amounts of feed delivered to the animals were adjusted. Feeding rates ranged from 10.5\% (initial) to 5.3\% (final). Daily, dry molasses (Indumel, Biosev, Sertãozinho, SP) was applied to adjust the C: $N$ ratio of water to 15: 1. The amount of molasses applied in each experimental unit was obtained using the formula presented by Avnimelech ${ }^{(17)}$, which consider the tank feeding management as follows: total ammonia nitrogen $(\mathrm{g} / \mathrm{tank} /$ day $)=$ commercial diet allowed $(\mathrm{g} / \mathrm{tank} / \mathrm{day}) * \% \mathrm{~N}$ diet * 0.5 .

Suspended solids were removed twice a week by sedimentation of $20 \%$ tank volume. That procedure was always performed when the concentrations of settleable solids exceeded $30 \mathrm{~mL} \mathrm{~L}^{-1}$. The supernatant was then returned to its respective tank. Sodium bicarbonate was applied to maintain the total alkalinity and $\mathrm{pH}$ of water at values equal to or greater than $60 \mathrm{mg} \mathrm{L}^{-1} \mathrm{CaCO}_{3}$ eq. and 7.0, respectively.

Water quality was evaluated as follows: $\mathrm{pH}$ (pH meter mPA210 - MS Tecnopon ${ }^{\circledR}$ ), temperature, specific conductance (conductivity meter CD-850) and dissolved oxygen (oximeter YSI55), daily at 9 h; total alkalinity (titration with a standard $\mathrm{H}_{2} \mathrm{SO}_{4}$ solution), total ammonia nitrogen (TAN; indophenol method), nitrite (sulfanilamide method) and nitrate (Cd-column reduction method), weekly; free carbon dioxide (free $\mathrm{CO}_{2}$; titration with a standard $\mathrm{Na}_{2} \mathrm{CO}_{3}$ solution), total hardness (titration with a standard EDTA solution), reactive phosphorus (molybdenum blue method), dissolved iron (thiocyanate method) and organic matter (oxygen consumed method), fortnightly. The determinations of water quality were carried out according to Clesceri et al.(19). The concentrations of total suspended solids were weekly determined, following the recommendations of Boyd and Tucker ${ }^{(20)}$.

Growth performance variables were monitored over the study: survival, final body weight, weekly weight gain, specific growth rate (SGR = [In (final weight) - In (initial weight)]/days of cultivation) $\times 100$ ), fish yield, feed conversion ratio (FCR $=$ dietary allowance/body weight gain) and protein efficiency ratio (PER = fish weight gain/dietary protein allowance).

The bioflocs' proximate composition was determined by the procedures indicated by $A O A C^{(21)}$ to crude protein (Kjeldahl method), ether extract (Soxhlet method), ash (muffle oven incineration) and moisture (drying at $105^{\circ} \mathrm{C}$ for $24 \mathrm{~h}$ ).

Results were tested by One-way ANOVA for completely randomized experiments. When there was a significant difference $(p<0.05)$ between treatments, the means were compared pairwise using the Tukey's test. Assumptions of normal distribution and homogeneity of variance were checked. Polynomial regression was applied on the final body weight and feed conversion ratio (FCR) results, in which the DL-methionine supplementation levels was the independent variable. The optimal supplementation of DL-methionine was estimated for each growth performance variable using the expression $\mathrm{x}=-\mathrm{b} / 2 \mathrm{a}$, where $\mathrm{a}$ and $\mathrm{b}$ were the regression coefficients. Statistical analyses were run with the aid of the softwares SigmaPlot for Windows v.12 (Systat Software, Inc.) and Microsoft Excel 2016. 


\section{Results and discussion}

\section{Water quality}

No significant differences were detected between the treatments for dissolved oxygen, $\mathrm{pH}$, temperature, and total alkalinity of water ( $p>0.05$; Table 1$)$. The specific conductance (SC) of the water was significantly higher in tanks with no feed restriction, except for the tanks subjected to $2 \%$ DL-methionine supplementation. There was an increase in mineralization of the organic matter with greater feed intake in tanks supplemented with $2 \%$ methionine due to their greater fish growth. The input of nutrients raises the SC of the water, which could be used as an indicator of eutrophication ${ }^{(22)}$. BFT tanks tend to have high SC because they accumulate organic matter in water.

Table 1. Dissolved oxygen, $\mathrm{pH}$, specific conductance, temperature, and total alkalinity of water after $\mathbf{8}$ weeks rearing Nile tilapia juveniles subjected or not to feed restriction and supplemented with increasing levels of DL-methionine (mean $\pm \mathrm{sd}$.; $\mathbf{n}=5$ )

\begin{tabular}{|c|c|c|c|c|c|c|}
\hline $\begin{array}{c}\text { Feed } \\
\text { restriction } \\
(\%)\end{array}$ & $\begin{array}{c}\text { DL- } \\
\text { methionine } \\
\text { (\%) }\end{array}$ & $\begin{array}{l}\text { Dissolved } \\
\text { oxygen } \\
\left(\mathbf{m g ~ L}^{-1}\right)\end{array}$ & pH & $\begin{array}{c}\text { Specific } \\
\text { conductance } \\
\left.(\mu \mathrm{S} \mathrm{cm})^{-1}\right)\end{array}$ & $\begin{array}{c}\text { Temperature } \\
\left({ }^{\circ} \mathrm{C}\right)\end{array}$ & $\begin{array}{c}\text { Total alkalinity } \\
\text { (mg L-1 eq. } \\
\left.\mathrm{CaCO}_{3}\right)\end{array}$ \\
\hline 0 & 0.0 & $5.65 \pm 0.21$ & $7.28 \pm 0.10$ & $1643 \pm 36 a$ & $26.2 \pm 0.11$ & $141.9 \pm 9.0$ \\
\hline 25 & 0.0 & $5.74 \pm 0.14$ & $7.40 \pm 0.11$ & $1528 \pm 40 \mathrm{~b}$ & $26.2 \pm 0.13$ & $150.4 \pm 11.0$ \\
\hline 25 & 0.5 & $5.69 \pm 0.22$ & $7.42 \pm 0.11$ & $1530 \pm 39 b$ & $26.1 \pm 0.16$ & $151.3 \pm 10.7$ \\
\hline 25 & 1.0 & $5.72 \pm 0.15$ & $7.39 \pm 0.12$ & $1568 \pm 35 b$ & $26.1 \pm 0.13$ & $152.2 \pm 7.8$ \\
\hline 25 & 2.0 & $5.64 \pm 0.18$ & $7.35 \pm 0.12$ & $1581 \pm 40 \mathrm{ab}$ & $26.1 \pm 0.15$ & $144.7 \pm 8.4$ \\
\hline 25 & $1.0^{*}$ & $5.71 \pm 0.12$ & $7.37 \pm 0.08$ & $1558 \pm 27 b$ & $26.2 \pm 0.15$ & $149.4 \pm 12.1$ \\
\hline \multicolumn{2}{|c|}{ P-value } & NS & NS & $<0.001$ & NS & NS \\
\hline
\end{tabular}

DL-methionine was mixed with the artificial diet in all treatments except for that marked with an asterisk, in which methionine was mixed with dry molasses. In the same column, means with different letters are significantly different by Tukey's test $(P<0.05)$. NS $=$ Non-significant $(P>0.05)$.

The free $\mathrm{CO}_{2}$ and dissolved iron concentrations did not significantly differ between the treatments ( $p>0.05$; Table 2). Total hardness $(\mathrm{TH})$ of water in the tanks under no feed restriction was significantly higher, except for the tanks supplemented with $2 \%$ DLmethionine. Allowances of feed and molasses were greater in tanks with greater fish growth, which increased their TH. Da Costa et al. ${ }^{(23)}$ state that molasses is a product used for ruminant animal nutrition and that it receives mineral additives such as calcium. As the water $\mathrm{TH}$ expresses the concentrations of calcium and magnesium, the higher input of molasses increased $\mathrm{TH}$. 
Table 2. Total hardness, concentration of free $\mathrm{CO}_{2}$, reactive phosphorus, dissolved iron and organic matter in water after 8 weeks rearing Nile tilapia juveniles subjected or not to feed restriction and supplemented with increasing levels of DL-methionine (mean \pm sd.; $\mathbf{n}$ $=5$ ).

\begin{tabular}{ccccccc}
\hline $\begin{array}{c}\text { Fee } \\
\text { restriction } \\
(\%)\end{array}$ & $\begin{array}{c}\text { DL- } \\
\text { methionine } \\
(\%)\end{array}$ & $\begin{array}{c}\text { Total hardness } \\
\left(\mathbf{m g ~ L}^{-1} \text { eq. }\right. \\
\left.\mathbf{C a C O}_{3}\right)\end{array}$ & $\begin{array}{c}\text { Free } \mathrm{CO}_{2} \\
\left(\mathbf{m g ~ L}^{-1}\right)\end{array}$ & $\begin{array}{c}\text { Reactive } \\
\text { phosphorus } \\
\left(\mathbf{m g ~ L}^{-1}\right)\end{array}$ & $\begin{array}{c}\text { Dissolved } \\
\text { iron } \\
\left(\mathbf{m g ~ L}^{-1}\right)\end{array}$ & $\begin{array}{c}\text { Organic } \\
\text { matter } \\
\left(\mathbf{m g ~ L}^{-1}\right)\end{array}$ \\
\hline 0 & 0.0 & $331.3 \pm 18.1 \mathrm{a}$ & $14.8 \pm 2.8$ & $4.59 \pm 0.34 \mathrm{a}^{2}$ & $3.19 \pm 0.34$ & $806 \pm 24 \mathrm{a}$ \\
25 & 0.0 & $287.3 \pm 12.8 \mathrm{~b}$ & $11.8 \pm 2.9$ & $3.78 \pm 0.43 \mathrm{~b}$ & $2.79 \pm 0.18$ & $743 \pm 19 \mathrm{~b}$ \\
25 & 0.5 & $293.9 \pm 10.6 \mathrm{~b}$ & $11.8 \pm 2.8$ & $3.81 \pm 0.21 \mathrm{~b}$ & $2.75 \pm 0.15$ & $748 \pm 14 \mathrm{~b}$ \\
25 & 1.0 & $298.3 \pm 16.9 \mathrm{~b}$ & $12.2 \pm 3.0$ & $3.94 \pm 0.38 \mathrm{ab}$ & $2.84 \pm 0.25$ & $747 \pm 28 \mathrm{~b}$ \\
25 & 2.0 & $302.8 \pm 11.4 \mathrm{ab}$ & $13.4 \pm 3.2$ & $4.10 \pm 0.40 \mathrm{ab}$ & $2.88 \pm 0.29$ & $762 \pm 27 \mathrm{ab}$ \\
25 & 1.0 & $288.4 \pm 17.3 \mathrm{~b}$ & $13.1 \pm 3.6$ & $3.91 \pm 0.39 \mathrm{ab}$ & $2.79 \pm 0.36$ & $751 \pm 20 \mathrm{~b}$ \\
\multicolumn{2}{c}{ P-value } & $<0.001$ & $\mathrm{NS}$ & 0.019 & $\mathrm{NS}$ & 0.002 \\
\hline
\end{tabular}

DL-methionine was mixed with the artificial diet in all treatments except for that marked with an asterisk, in which methionine was mixed with dry molasses. In the same column, means with different letters are significantly different by Tukey's test $(P<0.05)$. NS $=$ Non-significant $(P>0.05)$.

The concentrations of reactive phosphorus were higher in tanks with no feed restriction $(\mathrm{P}<0.05)$, except by the tanks supplemented with 1.0 and $2.0 \%$ of DL-methionine (Table 2). Commercial fish diets contain considerable concentrations of phosphorus (0.5 $1.0 \%)$, mostly of phytic nature. As the feeding allowances were higher in tanks with $2 \%$ DL-methionine supplementation, the $\mathrm{P}$ excretion to water was proportionally higher in those tanks. Similar results were reported by Caldini et al. ${ }^{(18)}$, who attributed the higher concentrations of reactive phosphorus to the greater allowances of commercial diets.

Concentrations of organic matter were higher in tanks with no feed restriction $(p<0.05)$, except for the tanks supplemented with 2\% DL-methionine (Table 2). Since the fish growth was higher in the latter tanks, feed intake was greater in those units because the amounts of artificial diet were proportional to fish biomass.

As the regression slope between the level of DL-methionine supplementation (\%) and the concentration of TAN (mg L-1) was close to zero, there was no significant effects of methionine supplementation on ammonia (Figure 1).

This result suggests that the dietary supplementation with DL-methionine did not stimulate the formation of bioflocs, serving only as an extra nutrient for fish. Otherwise, it would be expected a TAN reduction caused by DL-methionine supplementation. The organic carbon source and the C: $\mathrm{N}$ ratio of water influence the bioflocs formation and structure, having an important impact on the absorption of TAN ${ }^{(11,24)}$.

Concentrations of nitrite concentrations were not significantly affected by DLsupplementation (Figure 2), suggesting that extra methionine did not stimulate the growth of Nitrobacter. This result strengthens the suggestion that DL-methionine served only as a nutrient for fish growth, not contributing to improve the water quality. 


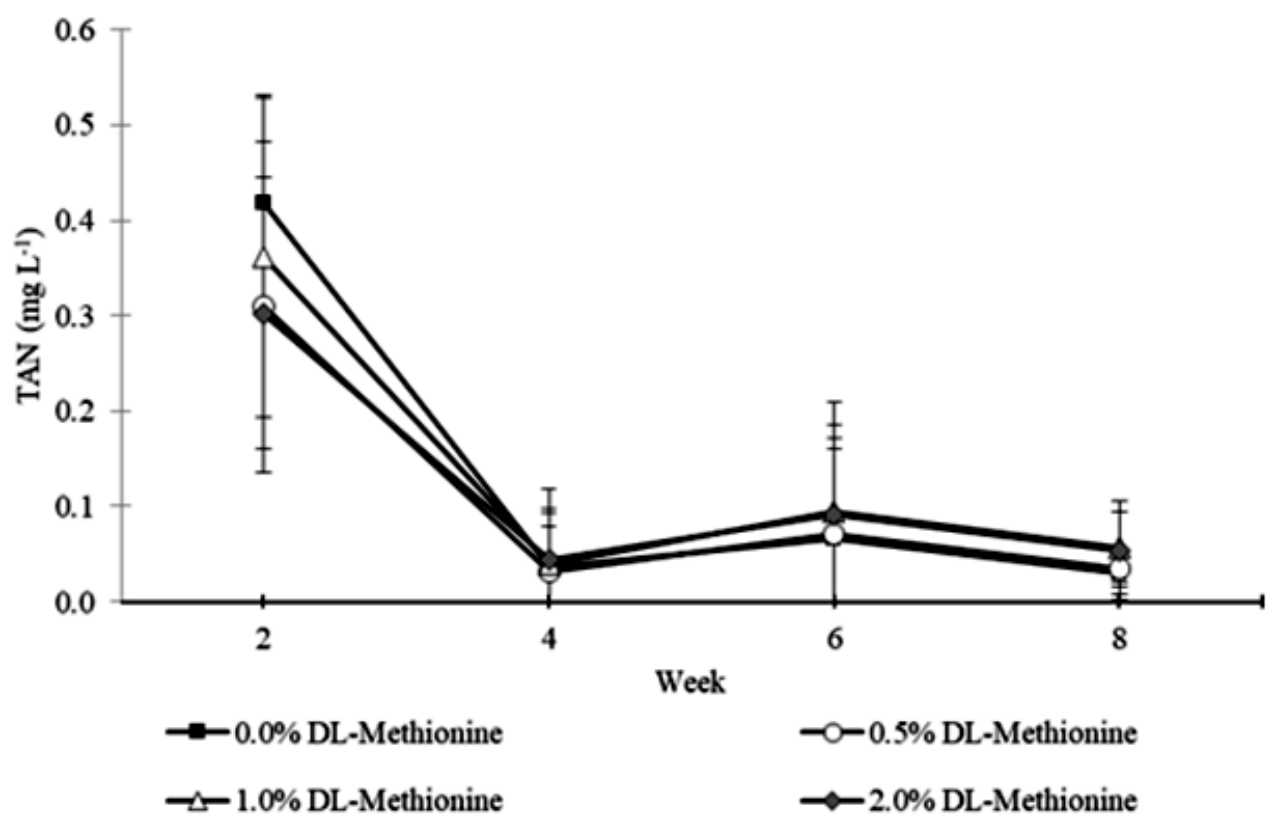

Figure 1. Concentration of total ammonia nitrogen in Nile tilapia BFT tanks subjected or not to feed restriction and supplemented with increasing levels of DL-methionine. At each time, the differences between the treatments are not significant $(P>0.05)$.

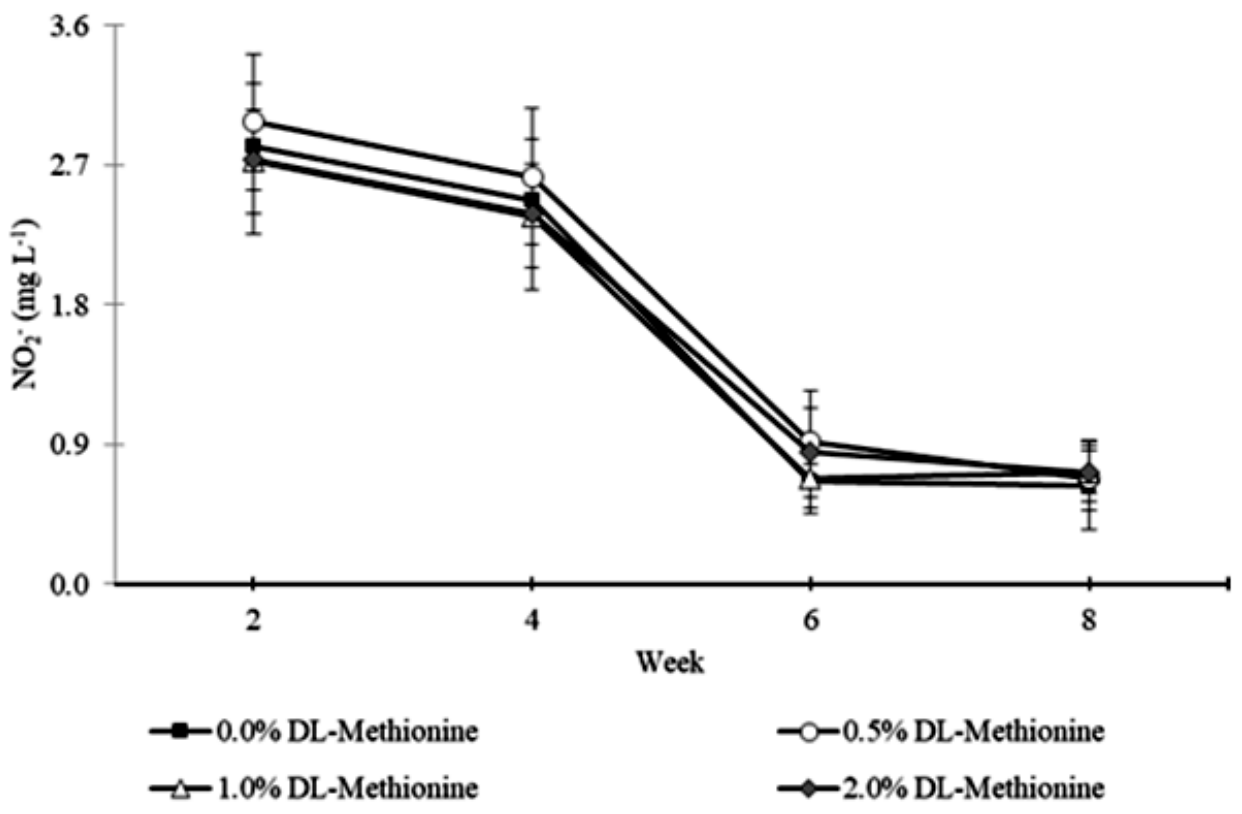

Figure 2. Nitrite in Nile tilapia BFT tanks subjected or not to feed restriction and supplemented with increasing levels of DL-methionine. At each time, the differences between the treatments are not significant $(P>0.05)$. 
Heterotrophic and nitrifying bacteria coexist in well-developed bioflocs tanks ${ }^{(1,25)}$. Those bacteria, however, might compete for ammonia, adhesion surface and micronutrients ${ }^{(24)}$. Heterotrophic bacteria develop quickly after the addition of a highly biodegradable organic carbon source to the tank, assimilating most of the ammonia. Nitrification, however, may have an increased importance and be responsible for removing up to $25-50 \%$ TAN $^{(26)}$. The main factors affecting nitrification in BFT systems are the concentrations of dissolved $\mathrm{O}_{2}$, ammonia and nitrite; the ratio $\mathrm{C}: \mathrm{N}, \mathrm{pH}$, temperature, and total alkalinity of water ${ }^{(27,28)}$.

Nitrate concentrations increased in all tanks over the experimental period and there was no influence of DL-methionine supplementation on nitrate (Figure 3).

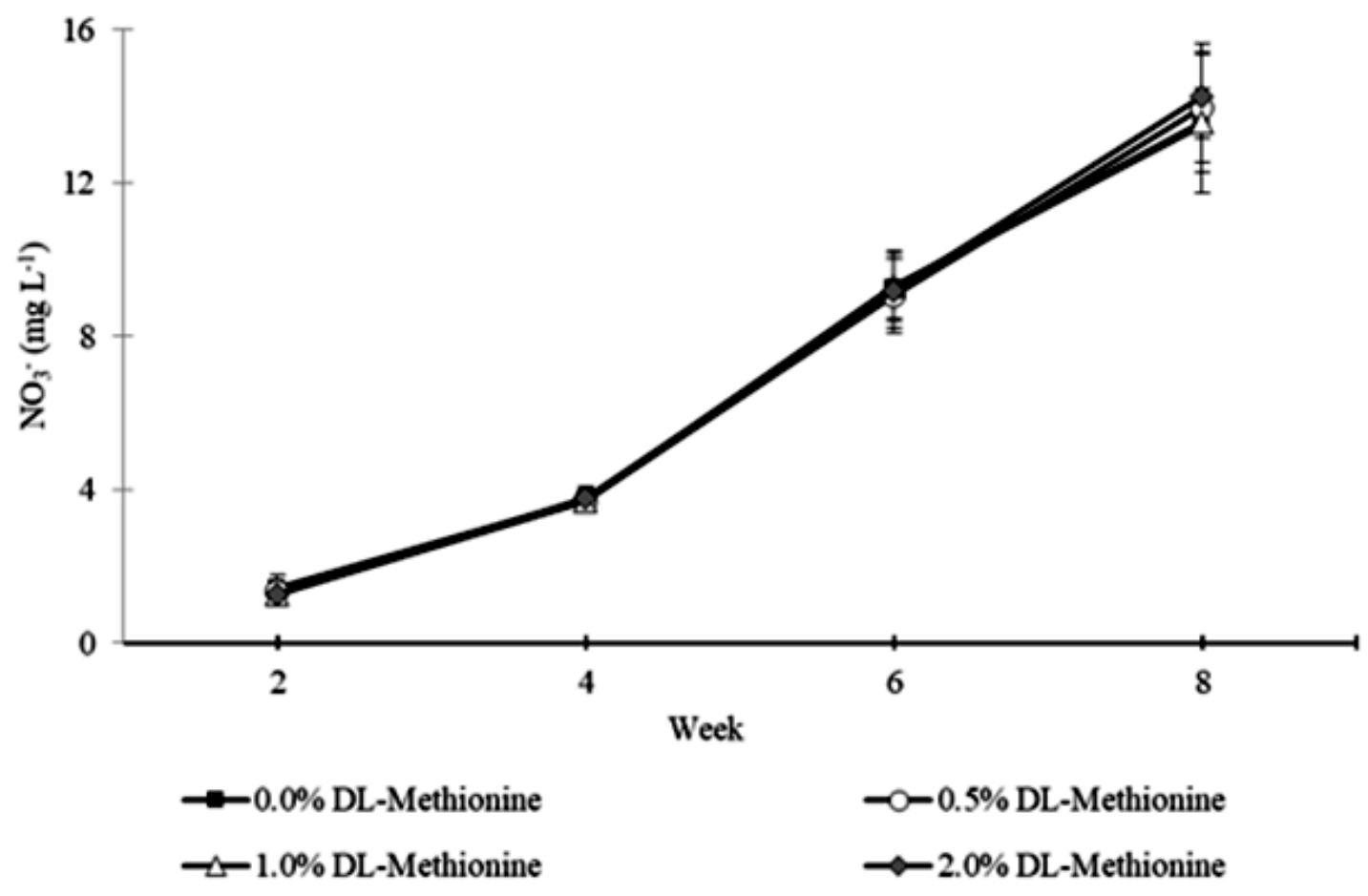

Figure 3. Nitrate in Nile tilapia BFT tanks subjected or not to feed restriction and supplemented with increasing levels of DL-methionine. At each time, the differences between the treatments are not significant $(P>0.05)$.

Nitrification occurs under aerobic conditions and consumes inorganic carbon in the form of bicarbonates ${ }^{(27)}$. Nitrate tends to accumulate in BFT and RAS tanks ${ }^{(29)}$. No significant effects on TAN, $\mathrm{NO}_{2}$ and $\mathrm{NO}_{3}{ }^{-}$were found in BFT L. vannamei(7) and Nile tilapia ${ }^{(30)}$ tanks when the animals fed diets with different protein levels.

The concentrations of total suspended solids (TSS) were significantly affected by the supplementation with DL-methionine (Figure 4). 

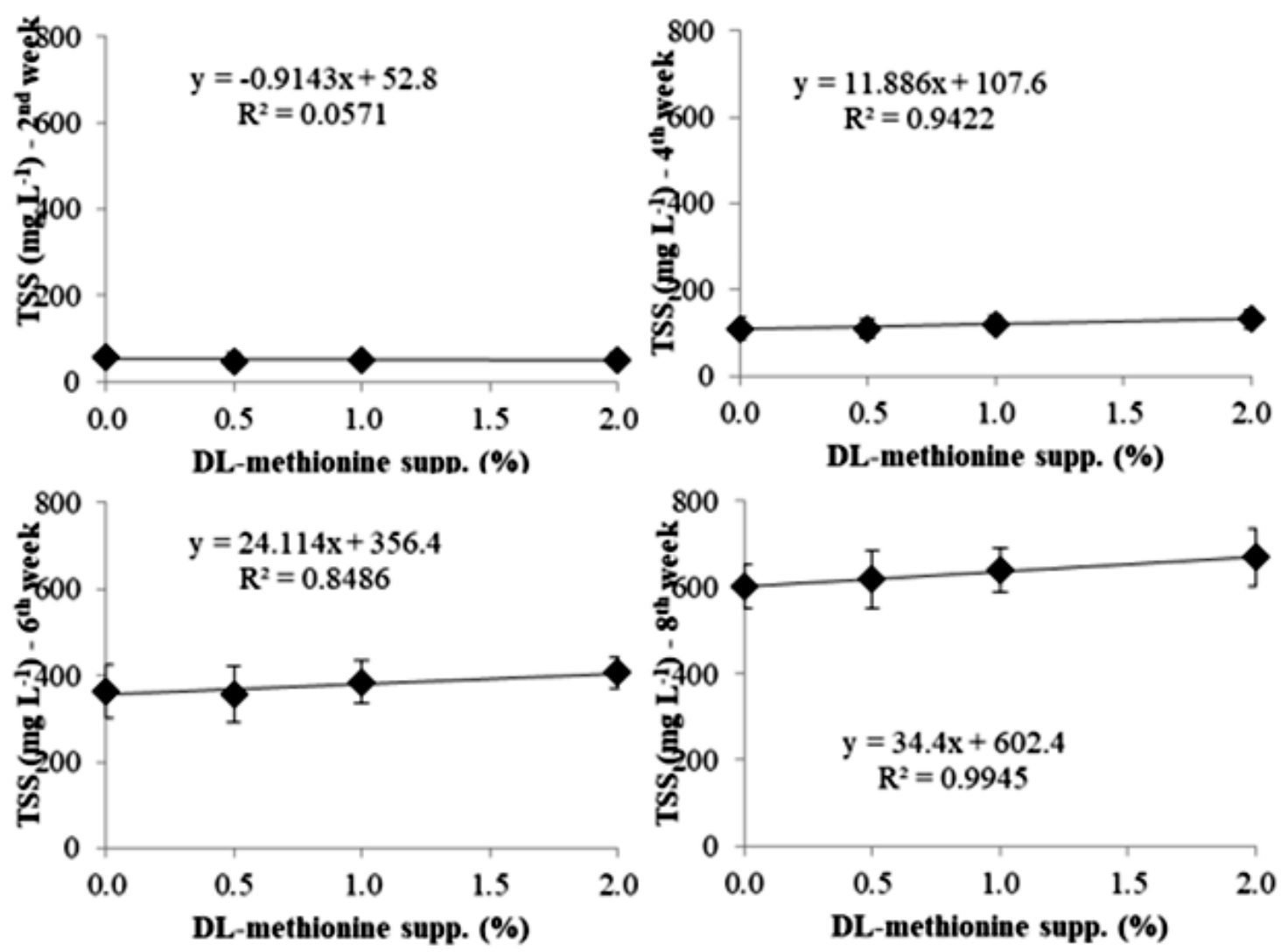

Figure 4. Concentrations of total suspended solids (TSS) in Nile tilapia, Oreochromis niloticus, BFT tanks. The commercial diet was supplemented with increasing levels of DL-methionine $(n=5)$.

DL-methionine supplementation favored fish weight gain in the present study (Table 4). Daily commercial diet and dry molasses inputs were higher in tanks with greater methionine supplementation because those actions were carried out in a way directly proportional to fish growth. More artificial diet produced more feces and more molasses and produced more bioflocs. As a result, there was a significant increase in TSS concentrations in tanks receiving more DL-methionine.

TSS concentrations should not exceed $500 \mathrm{mg} \mathrm{L}^{-1}$ in tilapia BFT tanks(26). The solids concentration in water should be managed to prevent fish gill clogging(31). As a preventive measure, it is recommended to use clarifiers to remove excess solids in BFT tanks.

Chemical composition of bioflocs

Bioflocs proximate composition was not affected by the dietary feed restriction or DL-methionine supplementation (Table 3; $\mathrm{P}>0.05$ ). The bioflocs moisture did not differ between the treatments $(P>0.05)$. Similarly, the different DL-methionine supplementation levels have not affected the bioflocs' crude protein, ether extract and 
ash contents.

Table 3. Proximate composition of bioflocs in Nile tilapia BFT tanks subjected or not to feed restriction and supplemented with increasing levels of DL-methionine (dry matter basis)

\begin{tabular}{cccccc}
\hline $\begin{array}{c}\text { Feed } \\
\text { restriction } \\
(\%)\end{array}$ & $\begin{array}{c}\text { DL- } \\
\text { methionine } \\
\text { (\%) }\end{array}$ & $\begin{array}{c}\text { Moisture } \\
\text { (\%) }\end{array}$ & $\begin{array}{c}\text { Crude protein } \\
\text { (\%) }\end{array}$ & $\begin{array}{c}\text { Ether extract } \\
\text { (\%) }\end{array}$ & $\begin{array}{c}\text { Ash } \\
\text { (\%) }\end{array}$ \\
\hline 0 & 0.0 & $88.87 \pm 0.84$ & $31.49 \pm 1.60$ & $2.07 \pm 0.17$ & $10.78 \pm 0.71$ \\
25 & 0.0 & $89.42 \pm 0.85$ & $31.31 \pm 1.87$ & $2.04 \pm 0.24$ & $10.33 \pm 0.52$ \\
25 & 0.5 & $89.90 \pm 0.88$ & $32.43 \pm 1.81$ & $2.18 \pm 0.15$ & $10.66 \pm 0.72$ \\
25 & 1.0 & $89.56 \pm 0.96$ & $31.45 \pm 1.79$ & $2.02 \pm 0.10$ & $10.72 \pm 0.88$ \\
25 & 2.0 & $89.99 \pm 0.70$ & $32.33 \pm 1.50$ & $2.07 \pm 0.18$ & $10.58 \pm 0.51$ \\
25 & $1.0^{\star}$ & $89.79 \pm 1.09$ & $31.94 \pm 1.99$ & $2.11 \pm 0.11$ & $10.60 \pm 0.63$ \\
& P-value & NS & NS & NS & NS \\
\hline
\end{tabular}

DL-methionine was mixed with the artificial diet in all treatments except for that marked with an asterisk, in which methionine was mixed with dry molasses. Mean \pm standard deviation $(n=3)$. NS $=$ Non-significant $(P>0.05)$.

The bioflocs' crude protein, moisture and ash values were similar to those observed by Gallardo-Collí, Pérez-Rostro and Hernández-Vergara ${ }^{(32)}$. These authors found 36\%, $86 \%$ and $11 \%$, respectively, for the same variables. Durigon et al.(13) and Rajkumar et al.(33) observed levels of ether extract of $1.2 \%$ and $0.9 \%$, respectively, values lower than in the present study. Therefore, the supplementation of DL-methionine mixed with the artificial diet or dry molasses did not nutritionally enrich the bioflocs. However, it would be important to determine the methionine concentration in bioflocs to check if there had not been an increase in that content.

As there was a positive effect of DL-methionine supplementation on fish growth in tanks subjected to feed restriction, the DL-methionine was probably used by fish as a nutrient. In general, bioflocs are deficient in methionine to meet the nutritional requirements of Nile tilapia and L. vannamei. The bioflocs reported by Wei, Liao and Wang ${ }^{(11)}$ and Ekasari et al. ${ }^{(15)}$ were deficient in methionine with concentrations below 20 $\mu \mathrm{mol} \mathrm{g} \mathrm{g}^{-1}$. One cause for the animal growth impairment when the individuals are given bioflocs biomass is their methionine deficiency ${ }^{(11,15,16)}$. Valle et al. ${ }^{(34)}$ recommended that the $L$. vannamei's diet should be supplemented with methionine when bioflocs meal is used as animal feed. A decrease in fish weight gain was expected in the tanks subjected to feed restriction. Since it has not occurred in tanks that receiving DL-methionine at $1 \%$ or $2 \%$, the intake of supplemental DL-methionine by fish was important in maintaining unchanged rates of animal growth.

Fish growth performance

Fish survival was equal to $91.3 \pm 1.8 \%$ with no significant difference between the 
treatments ( $p>0.05$; Table 4). The final body weight and SGR in tanks with no feed restriction were significantly higher than in the other treatments, except for the units with $1.0 \%$ or $2.0 \%$ DL-methionine. Those same variables were significantly lower in tanks with $1 \%$ DL-methionine mixed with molasses. Therefore, the optimal DL-methionine supplementation of Nile tilapia BFT subjected to feed restriction would be $1 \%$. Above that level there would be no clear growth performance advantages. Feed restriction aimed at increasing the bioflocs intake by fish. If well succeeded, a significant part of the fish nutrition would come from the ingestion of bioflocs. He et al. ${ }^{(35)}$ reported that the optimal inclusion level of L-methionine in Nile tilapia diets for maximum growth was $0.91 \%$ with $0.83 \mathrm{~g} \mathrm{~kg}^{-1}$ cysteine in the diet. According to the authors, methionine requirement for immunological integrity is greater than for maximum growth. In BFT tanks, fish are subjected to various stressors, such as high concentrations of nitrite and suspended solids in the water. Therefore, the requirements of tilapia for methionine might be even higher in BFT tanks.

DL-methionine supplementation should be via the commercial diet and not the molasses. Hence, DL-methionine was probably important only for fish nutrition and not for bioflocs' development. While the DL-methionine-artificial diet blend aimed at tilapia nutrition, the DL-methionine-molasses blend aimed at the bioflocs nutrition. The DLmethionine-molasses blend may have affected the amino acid stability, causing their loss to water by leaching, since the dry molasses absorbs moisture. Because crystalline DL-methionine is soluble in water its use is limited in aquatic diets. Leaching of 20\% DL-methionine may occur 30 minutes after its contact with water ${ }^{(36)}$. According to Guo et al.(37), the dipeptide DL-methionyl-DL-methionine (Met-Met) has an extremely low solubility in water and a better absorption than the other available sources of synthetic methionine, such as DL-methionine and L-methionine.

There were significant effects of feed restriction and supplementation with DLmethionine on fish weight gain and fish yield (Table 5). The highest fish yields were observed in tanks with no feed restriction and with feed restriction but 2\% DLmethionine supplementation. The lowest fish yields values were observed in tanks with feed restriction and not supplemented with DL-methionine or supplemented with 0.5\% and $1.0 \%$ methionine, the latter case when mixed with dry molasses.

Fish subjected to feed restriction was forced to ingest a greater amount of bioflocs to meet their nutritional requirements. It is assumed that bioflocs were able to partially meet the nutritional requirements of tilapia juveniles because no significant differences were detected on fish growth performance between the tanks with no feed restriction and the tanks under 25\% feed restriction but supplemented with 1\% DL-methionine. Therefore, dietary supplementation with DL-methionine played a key role because fish in tanks subjected to feed restriction but with no methionine supplementation grew significantly less. It is speculated that bioflocs' deficiency in methionine was indirectly offset by the dietary DL-methionine supplementation. A more economical feed management for tilapia BFT systems might have been found if the present results were confirmed by further studies carried out on a larger scale. This finding would contribute to give greater economic sustainability for tilapia aquaculture in BFT tanks. 
Table 4. Survival, final body weight and specific growth rate (SGR) of Nile tilapia juveniles (initial body weight of $2.76 \pm 0.06 \mathrm{~g}$ ) maintained for 8 weeks in BFT tanks subjected or not to feed restriction and supplemented with increasing levels of DLmethionine (mean $\pm s d ; n=5$ )

\begin{tabular}{|c|c|c|c|c|}
\hline $\begin{array}{c}\text { Feed restriction } \\
\text { (\%) }\end{array}$ & $\begin{array}{c}\text { DL- } \\
\text { methionine } \\
(\%)\end{array}$ & $\begin{array}{c}\text { Survival } \\
\text { (\%) }\end{array}$ & $\begin{array}{c}\text { Final body weight } \\
\text { (g) }\end{array}$ & $\begin{array}{c}\text { SGR } \\
\left(\% \text { day }^{-1}\right)\end{array}$ \\
\hline 0 & 0.0 & $90.0 \pm 6.0$ & $20.1 \pm 1.2 \mathrm{a}$ & $3.53 \pm 0.11 a$ \\
\hline 25 & 0.0 & $90.0 \pm 7.2$ & $17.5 \pm 0.4 b$ & $3.30 \pm 0.07 b$ \\
\hline 25 & 0.5 & $94.4 \pm 5.5$ & $17.3 \pm 0.7 b$ & $3.29 \pm 0.10 b$ \\
\hline 25 & 1.0 & $92.2 \pm 6.3$ & $18.7 \pm 1.5 \mathrm{ab}$ & $3.41 \pm 0.15 a b$ \\
\hline 25 & 2.0 & $91.1 \pm 8.4$ & $20.0 \pm 0.7 a$ & $3.56 \pm 0.08 a$ \\
\hline 25 & $1.0^{*}$ & $90.0 \pm 4.6$ & $17.9 \pm 1.2 b$ & $3.35 \pm 0.13 b$ \\
\hline \multicolumn{2}{|c|}{ P-value } & NS & $<0.001$ & $<0.001$ \\
\hline
\end{tabular}

DL-methionine was mixed with the artificial diet in all treatments except for that marked with an asterisk, in which methionine was mixed with dry molasses. SGR = [ln (final weight) $-\ln$ (initial weight)] $/$ days of rearing $\times 100)$. Means with different letters, in the same column, are significantly different by Tukey's test $(P<0.05)$. NS $=$ Non-significant ( $P>0.05)$.

Table 5. Weekly weight gain, fish yield and protein efficiency ratio (PER) of Nile tilapia juveniles maintained in BFT tanks subjected to feed restriction and supplemented with increasing levels of DL-methionine (mean $\pm S D ; n=5$ ).

\begin{tabular}{ccccc}
\hline $\begin{array}{c}\text { Feed restriction } \\
(\%)\end{array}$ & $\begin{array}{c}\text { DL- } \\
\text { methionine } \\
(\%)\end{array}$ & $\begin{array}{c}\text { Weekly weight gain } \\
\text { (g) }\end{array}$ & $\begin{array}{c}\text { Fish yield } \\
\left(\mathbf{g ~ m}^{-3} \text { day }\right.\end{array}$ & PER \\
\hline 0 & 0.0 & $2.17 \pm 0.15 \mathrm{a}$ & $58.7 \pm 1.4 \mathrm{a}$ & $2.23 \pm 0.03 \mathrm{c}$ \\
25 & 0.0 & $1.84 \pm 0.06 \mathrm{~b}$ & $50.6 \pm 3.7 \mathrm{c}$ & $2.61 \pm 0.18 \mathrm{~b}$ \\
25 & 0.5 & $1.82 \pm 0.09 \mathrm{~b}$ & $52.5 \pm 4.1 \mathrm{c}$ & $2.67 \pm 0.22 \mathrm{~b}$ \\
25 & 1.0 & $1.99 \pm 0.19 \mathrm{ab}$ & $55.1 \pm 2.4 \mathrm{~b}$ & $2.83 \pm 0.08 \mathrm{ab}$ \\
25 & 2.0 & $2.17 \pm 0.09 \mathrm{a}$ & $58.7 \pm 5.2 \mathrm{a}$ & $3.10 \pm 0.25 \mathrm{a}$ \\
25 & $1.0^{*}$ & $1.90 \pm 0.16 \mathrm{~b}$ & $51.8 \pm 2.9 \mathrm{c}$ & $2.72 \pm 0.09 \mathrm{~b}$ \\
& & $<0.001$ & 0.004 & $<0.001$ \\
\hline
\end{tabular}

DL-methionine was mixed with the artificial diet in all treatments except for that marked with an asterisk, in which methionine was mixed with dry molasses. PER = fish weight gain (g)/dietary protein allowance $(\mathrm{g})$. Means with different letters, in the same column, are significantly different by Tukey's test $(P<0.05)$. 
Better FCR and PER results were observed in tanks with feed restriction and supplementation of $2 \%$ DL-methionine, except for tanks receiving $1 \%$ DL-methionine mixed with the commercial diet (Table 5 and Figure 5). The worst results of FCR and PER were found in tanks with no feed restriction. These results differ from Cavalcante et al. ${ }^{(38)}$, who have not observed significant differences for FCR and PER in BFT tanks with and without feed restriction. The better FCR and PER results in tanks with feed restriction could be explained by their greater bioflocs intake. Therefore, the best treatment in the present study was the dietary supplementation with $1 \% \mathrm{DL}$-methionine. A still unanswered question is whether the DL-methionine and commercial diet blend would favor fish performance if larger size pellets were used. The powdered artificial diet allowed a homogeneous blend with DL-methionine.

A significant and direct effect of the DL-methionine supplementation level on fish final body weight was observed (Figure $5 \mathrm{~A}$ ). Besides, DL-methionine supplementation showed an inverse relationship with FCR $(P<0.05$; Figure $5 B)$. These trends were also observed by Figueiredo-Silva et al. ${ }^{(39)}$ in a study with hybrid tilapia, O. niloticus $\times 0$. mossambicus. The authors have reported that dietary methionine increase resulted in higher final body weight, specific growth rate and protein efficiency ratio. Therefore, the dietary supplementation of DL-methionine could improve the Nile tilapia growth performance in BFT tanks and allow savings with commercial diet purchases.
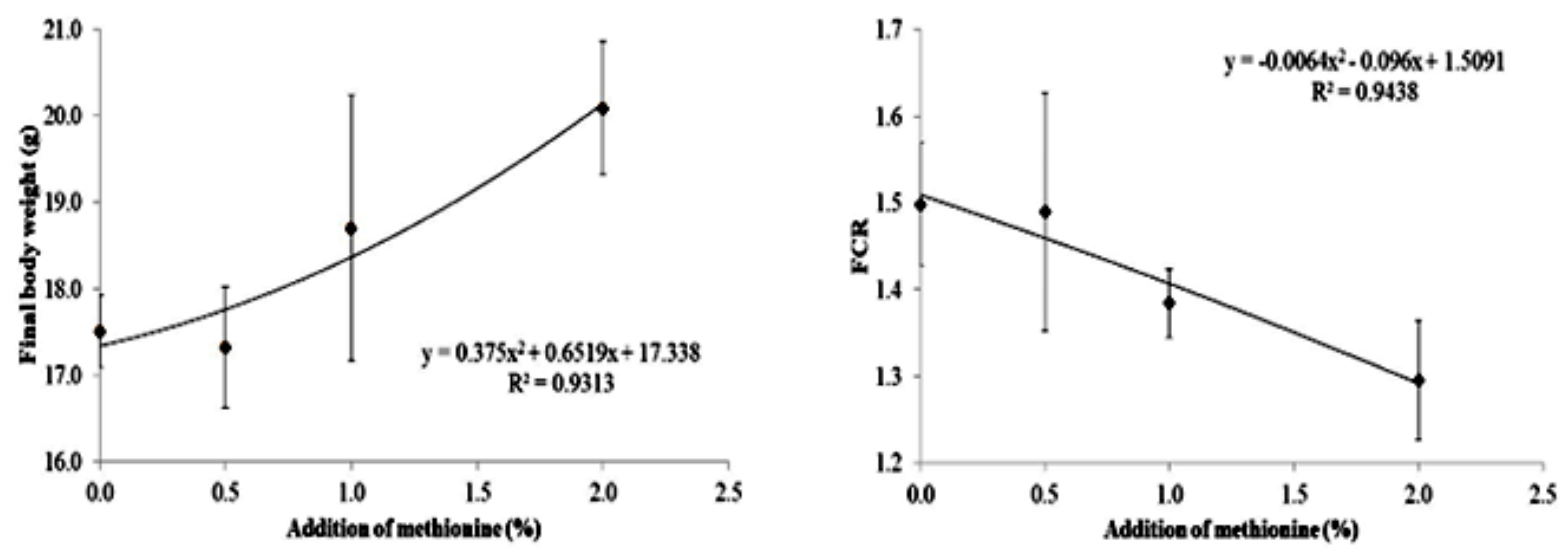

\section{Figure 5 - Final body weight and feed conversion ratio (FCR) of Nile tilapia juveniles maintained in BFT tanks subjected to feed restriction and supplemented with increasing levels of DL-methionine (mean $\pm s d ; n=5$ ).}

Dietary DL-methionine supplementation in tilapia BFT systems subjected to moderate feed restriction has a favorable cost: benefit ratio, as could be seen by the following example: 1 - commercial diet's cost: R\$5.60 kg-1; 2 - DL-methionine's cost: R $\$ 20.00 \mathrm{~kg}^{-1}$; 3 - fish biomass: $1.0 \mathrm{~kg} \mathrm{~m}^{-3}$; fish body weight: $2.0 \mathrm{~g}$. In this case, the daily feeding rate would be $11.3 \%$. Accordingly, the daily feed allowance and cost with commercial diet 
would be equal to $113 \mathrm{~g} \mathrm{~m}^{-3}$ and $\mathrm{R} \$ 0.63 \mathrm{~m}^{-3}$ day $^{-1}$, respectively. There would be savings of $\mathrm{R} \$ 0.16 \mathrm{~m}^{-3}$ day $^{-3}$ with the $25 \%$ feed restriction. On the other hand, DL-methionine supplementation at the $1 \%$ and $2 \%$ would result in increases of $R \$ 0.02$ and $R \$ 0.04$ $\mathrm{m}^{-3}$ day $^{-1}$, respectively. Therefore, there would be final savings of $\mathrm{R} \$ 0.14$ and $\mathrm{R} \$ 0.12$ $\mathrm{m}^{-3}$ day $^{-1}$, respectively, when the strategies of feed restriction and the DL-methionine supplementation are employed simultaneously.

\section{Conclusions}

Supplementation of commercial diets for Nile tilapia with DL-methionine did not affect the water quality of BFT tanks, nor the bioflocs' proximate composition. It may be possible to reduce the tilapia's feeding rates by $25 \%$ with no growth performance impairment if the commercial diets are supplemented with $1 \%$ or more DL-methionine.

\section{Conflict of interest}

The authors declare no conflict of interest.

\section{References}

1. De Schryver P, Crab R, Defoirdt T, Boon N, Verstraete W. The basics of bio-flocs technology: the added value for aquaculture. Aquaculture. 2008 Jun; 277(3-4): 125-137. Disponível em: http://www.sciencedirect. com/science/article/pii/S0044848608000896.

2. Kumar V S, Pandey P K, Anand T, Bhuvaneswari G R, Dhinakaran A, Kumar S. Biofloc improves water, effluent quality and growth parameters of Penaeus vannamei in an intensive culture system. Journal of Environmental Management. 2018 Jun; 215(1): 206-215. Disponível em: http://www.sciencedirect.com/ science/article/pii/S030147971830238X.

3. Azim M E, Little D C. The biofloc technology (BFT) in indoor tanks: Water quality, biofloc composition, and growth and welfare of Nile tilapia (Oreochromis niloticus). Aquaculture. 2008 Oct; 283(1-4):29-35. Disponível em: http://www.sciencedirect.com/science/article/pii/S0044848608004699.

4. Avnimelech Y. Biofloc technology: A pratical guide book. Baton Rouge, Louisiana, United States, The World Aquaculture Society. 2009, 182 p.

5. Long L, Yang J, Li Y, Guan C, Wu F. Effect of biofloc technology on growth, digestive enzyme activity, hematology, and immune response of genetically improved farmed tilapia (Oreochromis niloticus). Aquaculture. 2015 Nov; 448 (1): 135-141. Disponível em: http://www.sciencedirect.com/science/article/ pii/S0044848615300089

6. Kuhn D D, Boardman G D, Lawrence A L, Marsh L, Flick G J. Microbial flocs generated in bioreactors is a superior replacement ingredient for fishmeal or soybean meal in shrimp feed. Aquaculture. 2009 Nov; 296(1-2): 51-57. Disponível em: http://www.sciencedirect.com/science/article/pii/S0044848609006619.

7. Xu W J, Pan L Q, Zhao D H, Huang J. Preliminary investigation into the contribution of bioflocs on protein nutrition of Litopenaeus vannamei fed with different dietary protein levels in zero-water exchange culture tanks. Aquaculture. 2012 Jun; 350(1): 147-153. Disponível em: http://www.sciencedirect.com/science/ article/pii/S0044848612002074.

8. da Silva M A, de Alvarenga E R, Alves G F O, Manduca L G, Turra E M, de Brito T S, de Sales S C M, da Silva 
Junior A F, Borges W J M, Teixeira E A. Crude protein levels in diets for two growth stages of Nile tilapia (Oreochromis niloticus) in a biofloc system. Aquaculture research. 2018 Jun; 49(8): 2693-2703. Disponível em: https://doi.org/10.1111/are.13730.

9. Green B W, Rawles S D, Schrader K K, Gaylord T G, McEntire M E. Effects of dietary protein content on hybrid tilapia (Oreochromis aureus $\times$ O. niloticus) performance, common microbial off-flavor compounds, and water quality dynamics in an outdoor biofloc technology production system. Aquaculture. 2019 Mar; 503(1): 571-582. Disponível em: http://www.sciencedirect.com/science/article/pii/S0044848618320805.

10. Emerenciano M, Ballester E L, Cavalli R O, Wasielesky W. Effect of biofloc technology (BFT) on the early postlarval stage of pink shrimp Farfantepenaeus paulensis: growth performance, floc composition and salinity stress tolerance. Aquaculture International. 2011 Oct; 19(5): 891-901. Disponível em: https://doi. org/10.1007/s10499-010-9408-6.

11. Wei Y F, Liao S A, Wang A L. The effect of diferente carbon sources on the nutritional composition, microbial community and structure of bioflocs. Aquaculture. 2016 Dec; 465(1): 88-93. Disponível em: http://www.sciencedirect.com/science/article/pii/S0044848616304410.

12. Ballester E L C, Abreu P C, Cavalli R O, Emerenciano M, De Abreu L, Wasielesky Jr W. Effect of practical diets with different protein levels on the performance of Farfantepenaeus paulensis juveniles nursed in a zero exchange suspended microbial flocs intensive system. Aquaculture Nutrition. 2010 Mar; 16(2): 163172. Disponível em: https://doi.org/10.1111/j.1365-2095.2009.00648.x.

13. Durigon E G, Lazzari R, Uczay J, de Alcântara Lopes D L, Jerônimo G T, Sgnaulin T, Emerenciano M G C. Biofloc technology (BFT): Adjusting the levels of digestible protein and digestible energy in diets of Nile tilapia juveniles raised in brackish water. Aquaculture and Fisheries. 2020 Ján; 5(1): 42-51. Disponível em: https://doi.org/10.1016/j.aaf.2019.07.001.

14. Bauer W, Prentice-Hernandez C, Tesser M B, Wasielesky Jr W, Poersch L H. Substitution of fishmeal with microbial floc meal and soy protein concentrate in diets for the pacific white shrimp Litopenaeus vannamei. Aquaculture. 2012 Apr; 342-343: 112-116. Disponível em: http://www.sciencedirect.com/ science/article/pii/S0044848612001147.

15. Ekasari J, Angela D, Waluyo S H, Bachtiar T, Surawidjaja E H, Bossier P, De Schryver P. The size of biofloc determines the nutritional composition and the nitrogen recovery by aquaculture animals. Aquaculture. 2014 Apr; 426-427: 105-111. Disponível em: https://doi.org/10.1016/j.aquaculture.2014.01.023.

16. Li J, Liu G, Li C, Deng Y, Tadda M A, Lan L, Zhu S, Liu D. Effects of different solid carbon sources on water quality, biofloc quality and gut microbiota of Nile tilapia (Oreochromis niloticus) larvae. Aquaculture. 2018 Oct; 495:919-931. Disponível em: https://doi.org/10.1016/j.aquaculture.2018.06.078.

17. Avnimelech Y. Carbon/nitrogen ratio as a control element in aquaculture systems. Aquaculture. 1999 Jun; 176(3-4): 227-235. Disponível em: https://doi.org/10.1016/S0044-8486(99)00085-X.

18. Caldini N N, Capistrano H H D A, Rocha Filho P R N, Carmo e Sá M V. Partial replacement of artificial diets by wet bioflocs biomass in Nile tilapia culture tanks. Acta Scientiarum. Animal Sciences. 2018 Oct; 40:1-8. Disponível em: https://doi.org/10.4025/actascianimsci.v40i1.42426.

19. Clesceri LS, Greenberg A E, Eaton AD. Standard Methods for the Examination of Water and Wastewater. 20.ed. Washington, DC: American Public Health Association; 1998.

20. Boyd C E, Tucker C S. Water quality and pond soil analyses for aquaculture. Auburn University, Opelika, USA, 1992. 183pp.

21. AOAC. Association of Official Analytical Chemistry. Official Methods of Analysis, 17th ed, Washington, D.C.USA, 2000.

22. Harris, T.D., Graham, J.L. Predicting cyanobacterial abundance, microcystin, and geosmin in a 
Dietary supplementation of tilapia juveniles reared in bft (bioflocs) tanks with dl-methionine Lima F R S et al.

eutrophic drinking-water reservoir using a 14-year dataset. Lake and Reservoir Management. 2017. 33. Disponível em: https://pubs.er.usgs.gov/publication/70181018

23. da Costa D A, de Souza C L, Saliba E D O S, Carneiro J D. By-products of sugar cane industry in ruminant nutrition. Int. J. Adv. Agric. Res. 2015 Feb; 3: 1-95. Disponível em: http://www.bluepenjournals.org/ijaar/ pdf/2015/March/da_Costa et_al.pdf.

24. Xu W, Morris T C, Samocha T M. Effects of C/N ratio on biofloc development, water quality, and performance of Litopenaeus vannamei juveniles in a biofloc-based, high-density, zero-exchange, outdoor tank system. Aquaculture. 2016 Feb; 453:169-175. Disponível em: https://doi.org/10.1016/j. aquaculture.2015.11.021.

25. Zhang J, Chen L, Dong H, Duan Y, Li Z, Wen G, Chen J, Zhenhua Feng Z, Xu W, Xie J. Artificial substrates in zero-water-exchange culture system regulate the rearing performance of Pacific white shrimp Litopenaeus vannamei (Boone, 1931) under the winter indoor condition. Aquaculture research. 2016 Ján; 47(1): 91-100. Disponível em: https://doi.org/10.1111/are.12473.

26. Hargreaves, J.A. Biofloc Production Systems for Aquaculture. Southern Regional Aquaculture Centre, No. 4503, 2013.

27. Ebeling J M, Timmons M B, Bisogni J J. Engineering analysis of the stoichiometry of photoautotrophic, autotrophic, and heterotrophic removal of ammonia-nitrogen in aquaculture systems. Aquaculture. 2006 Jun; 257(1-4): 346-358. Disponível em: https://doi.org/10.1016/j.aquaculture.2006.03.019.

28. Luo G, Zhang N, Cai S, Tan H, Liu Z. Nitrogen dynamics, bacterial community composition and biofloc quality in biofloc-based systems cultured Oreochromis niloticus with poly- $\beta$-hydroxybutyric and polycaprolactone as external carbohydrates. Aquaculture. 2017 Oct; 479: 732-741. Disponível em: https://doi.org/10.1016/j.aquaculture.2017.07.017.

29. Luo G, Gao Q, Wang C, Liu W, Sun D, Li L, Tan H. Growth, digestive activity, welfare, and partial costeffectiveness of genetically improved farmed tilapia (Oreochromis niloticus) cultured in a recirculating aquaculture system and an indoor biofloc system. Aquaculture. 2014 Feb; 422-423: 1-7. Disponível em: https://doi.org/10.1016/j.aquaculture.2013.11.023.

30. Mansour A T, Esteban M A. Effects of carbon sources and plant protein levels in a biofloc system on growth performance, and the immune and antioxidant status of Nile tilapia (Oreochromis niloticus). Fish \& shellfish immunology. 2017 May; 64: 202-209. Disponível em: https://doi.org/10.1016/j.fsi.2017.03.025.

31. Ray A J, Lewis B L, Browdy C L, Leffler J W. Suspended solids removal to improve shrimp (Litopenaeus vannamei) production and an evaluation of a plant-based feed in minimal-exchange, superintensive culture systems. Aquaculture. 2010 Feb; 299(1-4): 89-98. Disponível em: https://doi.org/10.1016/j. aquaculture.2009.11.021.

32. Gallardo-Collí A, Pérez-Rostro C I, Hernández-Vergara M P. Reuse of water from biofloc technology for intensive culture of Nile tilapia (Oreochromis niloticus): effects on productive performance, organosomatic indices and body composition. International Aquatic Research. 2019 Feb; 11(1): 43-55. Disponível em: https://link.springer.com/article/10.1007/s40071-019-0218-9.

33. Rajkumar M, Pandey P K, Aravind R, Vennila A, Bharti V, Purushothaman C S. Effect of different biofloc system on water quality, biofloc composition and growth performance in Litopenaeus vannamei (Boone, 1931). Aquaculture research. 2016 May; 47(11): 3432-3444. Disponível em: https://doi.org/10.1111/ are.12792.

34. Valle B C S, Dantas Jr E M, Silva J F X, Bezerra R S, Correia E S, Peixoto S R M, Soares R B. Replacement of fishmeal by fish protein hydrolysate and biofloc in the diets of Litopenaeus vannamei postlarvae. Aquaculture Nutrition. 2015 Nov; 21(1): 105-112. Disponível em: https://doi.org/10.1111/anu.12149.

35. He J Y, Long W Q, Han B, Tian LX, Yang H J, Zeng S L, Liu YJ. Effect of dietary I-methionine concentrations 
on growth performance, serum immune and antioxidative responses of juvenile Nile tilapia, Oreochromis niloticus. Aquaculture research. 2017 Oct; 48(2): 665-674. Disponível em: https://doi.org/10.1111/ are.12913.

36. Yuan Y C, Gong S Y, Yang H J, Lin Y C, Yu D H, Luo Z. Effects of supplementation of crystalline or coated lysine and/or methionine on growth performance and feed utilization of the Chinese sucker, Myxocyprinus asiaticus. Aquaculture. 2011 Jun; 316(1-4): 31-36. Disponível em: https://doi.org/10.1016/j. aquaculture.2011.03.015

37. Guo, T Y, Zhao W, He J Y, Liao S Y, Xie J J, Xie S W, Masagounder K, Liu Y J, Tian L X, Niu J. Dietary dl-methionyl-dl-methionine supplementation increased growth performance, antioxidant ability, the content of essential amino acids and improved the diversity of intestinal microbiota in Nile tilapia (Oreochromis niloticus). British Journal of Nutrition. 2020 Aug; 123(1): 72-83. Disponível em: https://doi. org/10.1017/S0007114519002289.

38. Cavalcante D D H, Lima F R D S, Rebouças V T, Carmo e Sá M V. Nile tilapia culture under feeding restriction in bioflocs and bioflocs plus periphyton tanks. Acta Scientiarum. Animal Sciences. 2017 Jul/Set; 39(3): 223-228. Disponível em: https://doi.org/10.4025/actascianimsci.v39i3.33574

39. Figueiredo-Silva, C., Lemme, A., Sangsue, D., \& Kiriratnikom, S. Effect of DL-methionine supplementation on the success of almost total replacement of fish meal with soybean meal in diets for hybrid tilapia (Oreochromis niloticus $\times$ Oreochromis mossambicus). Aquaculture Nutrition. 2015 Aug; 21(2): 234-241. Disponível em: https://doi.org/10.1111/anu.12150. 